\title{
ONLINE INSTRUCTION AS LOCAL EDUCATION: CUNY'S ONLINE BACCALAUREATE
}

George Otte

The City University of New York

\begin{abstract}
The City University of New York is taking a new, local approach to online instruction: offering an online baccalaureate for degree completers, designed for NYC students who have "stopped out" in good academic standing and need the "any time" flexibility of asynchronous learning to finish the degree. What is especially distinctive about this online program is its goal of access for local students, its core constituency and mission. Though CUNY is addressing a local problem, online access to higher education for local students may address nation-wide problems with rates of degree completion and progress towards completion. As more institutions provide online instruction, localness may well be the key to access and timely completion for local students, with time and not distance being the key obstacle it overcomes.
\end{abstract}

\section{KEYWORDS}

Online Learning, Degree Completion, Time to Degree, Localness

\section{INTRODUCTION}

\section{A. The Distance Traveled Since the Days of Distance Ed}

Throughout most of this young century, a series of Sloan surveys has been documenting the dramatic growth in online learning: Sizing the Opportunity: The Quality and Extent of Online Education in the United States, 2002 and 2003 [1], Entering the Mainstream: The Quality and Extent of Online Education in the United States, 2003 and 2004 [2], Growing by Degrees: Online Education in the United States, 2005 [3], and Making the Grade: Online Education in the United States, 2006 [4]. As the penultimate survey to date reports, "The number of students who study online has been increasing at a rate far in excess of the rate of growth in the overall higher education student population" [3]. The most recent notes that this remarkable growth is actually accelerating: "The more than 800,000 additional online students is more than twice the number added in any previous year" [4]. But there is always the question of when quantitative change shades into qualitative change, when a difference of degree becomes a difference of kind. And while the penetration continues and the number of students and courses grows, seemingly inexorably, there is a sense in which a corner has already been turned. As the second survey in the series, Entering the Mainstream, reported over two years ago, "Virtually all public institutions offer online courses..." [2]. What this means is a simple but compelling fact: If you're a student, and you want online instruction, you can get it locally. Distance ed has gone local.

\section{B. What Institutions Have to Ask Themselves}

For the students, and in their parlance, "It's all good." They have the convenience of online instruction combined with the comfort of the familiar: the traditional institution with the respect its instruction and especially its degrees have earned. Students can pursue online instruction from a variety of motives: curiosity or convenience, need or interest. They can mix and match modes, experiment, explore. 
Institutions, however, have to ask what this "turned corner" means for them because, after all, it presumably needs to mean something more than ad hoc exploration. If they are among the majority of those institutions that have made online instruction an option-the 2005 recent Sloan survey showed that nearly two-thirds of them have made at least some of the same courses that meet face-to-face available online as well [3] — then key questions have to be asked and critical decisions made.

- What will be the institutional driver for online instruction for local students? Why invest resources? How should the online option(s) be marketed?

- What are the risks? What, for instance, would prevent online instruction from simply drawing current students out of classrooms and off campuses, playing to convenience rather than need?

- What will keep institutions from poaching on their own constituencies, "raiding” what one mode already reaches by another?

- What are the risks of not engaging fully in offering online options for students? How will this affect the institution's relationship with partner institutions (especially in a multi-campus system) and above all its standing with competitors?

\section{Why Such Questions Are Well Worth Asking}

Institutions are not disposed to change. When they do, it usually happens with all the speed of a glacier moving uphill. For it to happen faster, there has to be a compelling reason to change, a problem to solve. Higher education actually has quite a few problems that could be significantly impacted by the growth of online instruction:

- Completion rates for baccalaureate degree programs at public institutions are at an all-time low (under 40\%) [5].

- Six out of every ten college students do not complete a bachelor's degree within six years of enrollment [6].

- The average time it takes students who do not stop out to complete a "4-year" degree is now a full 5 years [7].

- Those who do stop out are a worrisome unknown for institutions: as one report's title put it, "Stopouts or Stayouts?” [8].

Long before the recent release of the report of the Secretary of Education's Commission on the Future of Higher Education [9], with its emphasis on access and accountability, institutions of higher education have been working to address these problems—and, it seems, without much success.

But there is a new tool in the toolbox now, and we may have not yet begun to reckon just how powerful it might be. In addition to all the documented work with online learning, Blended Learning (partly oncampus, partly online learning) has generated particularly pervasive interest in the part of faculty as well as students, one tied to uses so grass-roots and under-the-radar we really don't know just how pervasive that interest is. We already do know that, according to data now over a year old, nearly $90 \%$ of American teenagers between the ages of 12-17 are on the Internet [10]. Meanwhile, Blended Learning (in CUNY, more than doubling the use of online instruction and the number of courses no longer meeting full-time in the classroom) has many instructors who are not yet willing to commit to fully online instruction preparing themselves to do just that. The faculty are increasingly ready, and the students are waiting.

And that's a good thing, because, again, online instruction has problems to solve. As a college degree becomes increasingly important economically as well as intellectually —and as the tuition it takes to get it keeps rising - the issues of time to degree and degree completion come with ever higher opportunity 
Online Instruction as Local Education: CUNY's Online Baccalaureate

costs. As students straining under these stop out altogether, higher education must find a means of reestablishing their access. What would a program that used online instruction to do that look like?

\section{THE CUNY ONLINE BACCALAUREATE PROGRAM}

\section{A. The Context}

The City University of New York is a union shop, and a union-imposed moratorium on "distance education" was in place until March of 2000. The moment it was lifted, CUNY began working intensively with online instruction, supported by funding from the Sloan Foundation. Hundreds of faculty were trained to offer online courses to thousands of students. Neither a campus nor even a discipline was untouched; online courses were offered at every kind and level of instruction. As the faculty development project reached deeper into the mainstream, hybrid or blended courses (half online, half on-campus) became an increasingly prevalent alternative to fully online instruction.

Still, the reasons to bring instruction online were largely up to the instructor. The University as a whole had all the students it could handle, literally on its doorstep. But soon changes-including both significant enrollment growth and substantial faculty hiring-prompted another look at what might be done with online instruction. The critical change was arguably a change at the top: the new Executive Vice Chancellor for Academic Affairs had been one of the prime movers behind UMass Online. And one of the things she noticed there was that most of those students shared her area code. Even and especially in multi-campus institution where all the colleges and their students were but a subway stop away from one another, now seemed to be the time to investigate the viability of an online degree.

\section{B. The Motives}

CUNY turned to its own institutional research, which showed that, over the last six years, 64,000 students left in good academic standing (with a GPA of 2.0 and a minimum of 30 earned credits) —and without enrolling anywhere else. (It must be remembered that this number is a reckoning, over more than half a decade, of "stop-outs" from an institution with close to a quarter of a million students pursuing degrees at any given point in time.) Focus groups revealed academic difficulty was not the issue for these students who stopped out, nor were problems with CUNY specifically. What then? To do a global paraphrase of the students queried, "Life happened" - the need to work full-time, to provide child care, and so on. And so, for so many, the door to a college degree was shut.

But online education can re-open that door, and it can do more than that. Asynchronous online instruction can eliminate the scheduling difficulties that have defeated so many students, but it can also, by virtue of its form of access, transform and heighten the nature of learning. Teaching traditional subjects, it can also teach what study in such fields becomes when study means not just access to information but what to do with the astonishing information resources now at our disposal. Online education can help students cope with a world where change keeps accelerating, and where the means of connection keep multiplying, and yet old as well as new kinds of division keep obtruding. It can show them what it means to learn-in life as well as in college-when that is less and less a matter of mastering a predefined content, more and more a matter of making connections and drawing conclusions from among the welter of facts and opinions thrown at us daily. It was that chance to address a profound need for access with an enhanced form of learning tailored to the modern world and workplace that made the development of an online degree such an exciting, inviting prospect. 


\section{The Methods}

Realizing that online education could eliminate the scheduling difficulties that have defeated so many students, CUNY decided on an online baccalaureate program for degree completers. It would speak directly to the matter of access, the heart of CUNY's mission, and it would allow the leveraging of all the work that it had done on online education-though now with the clear recognition that online instruction was also a critical need for a local population for whom time, not distance, is the issue.

But what kind of degree? All that work with online education presented an interesting possibility: the cherry-picking of successful online courses across the campuses, pulled together into a best-of-breed curriculum. But that would mean missing another opportunity: here was a chance to build a new degree without the legacies and territorial imperatives that would face such an endeavor at a traditional campus. The degree had to be in something, had to have a concentration, and making that a generic liberal arts concentration seemed oxymoronic. Here was a chance to develop a major uniquely suited to the world-asit-is, flattening or shrinking through communication networks but also pulled apart by diversity and division, reshaping itself with ever-escalating change.

Ultimately, these were not mutually exclusive choices. What a degree-completer's program most needed was a traditional take on general education, one that would maximize the transferability of credits the student came with. But that could be capped with an innovative, interdisciplinary major, an interweaving of social sciences leavened with communication and communication theory. That, ultimately, was the decision: a program with a strong liberal arts base but a genuinely unique interdisciplinary concentration characterized by courses like Global Culture and Diversity, Analyzing Organizational Structure and Change, and Studies in Mass Communication. Not a degree for everyone (there is no such animal), it is nevertheless a multivalent means of cultivating the thinking, communication, and research skills needed across a spectrum of job sectors and graduate programs today.

It was also important to think beyond the curriculum, to learn from the mistakes of programs created on the principle of "if you build it, they will come.” They might not come without effective marketing (plans for which focused on direct mail and local newspaper advertising as well as web-based prospecting). And it could even be a problem that they did come if the necessary support structures were not in place. So an extraordinary effort was made to ensure intensive student support including effective and consistent contact for applications, careful follow-through and prompt transfer credit evaluation, as well as ongoing advisement once students were admitted and enrolled.

\section{The Results So Far}

The program was approved by the CUNY community in January 2006, its Board of Trustees in February, and the New York State Education Department in March. Marketing began in April, the first applications were accepted in May, and registration for courses started in July. By August 30, the first day of the fall term, the program had 250 students (admitted from nearly twice as many applications). Averaging 3 courses each, the students' course enrollments took the program slightly past planned capacity (30 sections or 600 "seats"- the plan had always been to start well by starting small), but instructors waiting in the wings were able to accommodate student demand.

The faculty had spent the summer in an interactive site, sharing ideas and course sites with one another, raising questions of procedure and policy, experimenting with new tools (notably means of developing course-specific wikis and blogs). Like the students' 10-day online orientation prior to the term's start, the preparation paid off. The biggest surprise to date is how quiet things have been with the online help desk. 
And keeping the class sizes capped at 22 throughout the curriculum has meant the carefully planned online tutorial services seem underutilized - like the quiet help desk, another heartening non-problem.

The students themselves seem to be just those targeted. Most are former CUNY students. Nearly 200 of the 250 come from New York City. Of the remainder, those from elsewhere in the state are only slightly outnumbered by those from out-of-state, though that last subgroup does include a few international students. In terms of demographics, they seem to fit the general (and highly diverse) CUNY student profile by race, ethnicity, and gender, differing significantly only in tracking older. (The average age is 34, but that average shouldn't obscure an astonishing range that includes retirees as well as single parents in their early twenties.) As for why they come, each has a story-told in a personal statement that is part of the application, an explanation of why the online degree is the right choice and perhaps the only onebut a part that might stand for the whole is one student who noted that some years ago she felt she had to choose between a good job and a good education (and even later felt, in stopping out, that she had made the wrong choice); as she put it, the online degree meant she could have what she needed. Paying the bills and pursuing that ever more necessary degree no longer need to be mutually exclusive.

\section{CONCLUSION: A GENERATIONAL SHIFT?}

Small steps and small programs need to be careful of assuming too much significance. The road to yesterday's tomorrows is littered with the wreckage once touted as the coming thing. But online instruction has come a great distance, and it is time to ask whether the distance traveled doesn't entail some turned corners. Comparability with traditional instruction is no longer the challenge or burning issue it was; it's the baseline expectation. Once satellite and ancillary in some institutions, grass-roots and under-the-radar in others, online instruction is increasingly integral to the missions and goals of more and more institutions now, so much so that it has been argued that "the growth of online learning, its rhizomelike reach into all aspects of institutions of higher education, poses the intriguing possibility that we are converging on a single, integrative model, albeit from different directions" [11]. Maybe it is no longer a question of whether online learning has come of age. Maybe the question now is whether we have turned another corner, moved to a second- (or is it third) generation model, one where what was online instruction, once thought of as "distance ed," has gone local.

\section{REFERENCES}

1. Allen, I. E. and J. Seaman. Sizing the Opportunity: The Quality and Extent of Online Education in the United States, 2002 and 2003. Needham, MA: Sloan-C, 2003. http://www.sloan-c.org /publications/survey/pdf/sizing_the_opportunity.pdf.

2. Allen, I. E. and J. Seaman. Entering the Mainstream: The Quality and Extent of Online Education in the United States, 2003 and 2004. Needham, MA: Sloan-C, 2004. http://www.sloan-c.org /publications/survey/pdf/entering mainstream.pdf.

3. Allen, I. E. and J. Seaman. Growing by Degrees: Online Education in the United States, 2005. Needham, MA: Sloan-C, 2005. http://www.sloan-c.org/publications/survey/pdf/growing by degrees .pdf.

4. Allen, I. E. and J. Seaman. Making the Grade: Online Education in the United States, 2006. Needham, MA: Sloan-C, 2005. http://www.sloan-c.org/publications/survey/pdf/making the_grade .pdf.

5. 2006 Retention/Completion Summary Tables, National Collegiate Retention and Persistence to Degree Rates, ACT. http://www.act.org/path/policy/pdf/retain_trends.pdf. 
6. Carey, K. One Step From the Finish Line: Higher College-Graduation Rates are Within Our Reach. Education Trust, 2005. http://www2.edtrust.org/NR/rdonlyres/407EEA77-E5B5-42CB-8006EC1A09928E9D/0/onestep.pdf.

7. Student Effort and Educational Progress: Time to Bachelor's Degree Completion. http://nces.ed.gov /programs/coe/2003/section3/indicator21.asp.

8. Stopouts or Stayouts? Undergraduates Who Leave College. http://nces.ed.gov/pubs99/1999087.pdf.

9. A Test of Leadership: Charting the Future of U.S. Higher Education. http://www.ed.gov /about/bdscomm/list/hiedfuture/reports/pre-pub-report.pdf.

10. Lenhart, A., M. Madden, and P. Hitlin. Teens and technology: Youth are leading the transition to a fully wired and mobile nation. Pew Internet \& American Life Project, 2005. http://www .pewinternet.org/PPF/r/162/report_display.asp.

11. Otte, G. and M. Benke. Online Learning: New Models for Leadership and Organization in Higher Education. Journal of Asynchronous Learning Networks 10(2): May 2006. http://www.sloan-c.org /publications/JALN/v10n2/v10n2 2otte.asp.

\section{ABOUT THE AUTHOR}

A professor for over two decades, George Otte is on the doctoral faculties of the CUNY Graduate Center programs in English, Urban Education, and Technology \& Pedagogy. Since March 2001, when he was named Director of Instructional Technology for CUNY, he has been supervising CUNY Online, the City University's faculty/course development program for online instruction, supported by the Sloan Foundation. He is currently also Academic Director of the CUNY Online Baccalaureate Program. 